\title{
Studies on Bhartṛhari and the Pratyabhijñã: Language, Knowledge and Consciousness
}

\author{
Marco Ferrante ${ }^{1}$ (iD
}

Published online: 23 September 2019

(C) The Author(s) 2019

\begin{abstract}
The article examines the impact the grammarian/philosopher Bhartrinari (460-510) had on the way the 'School of Recognition' (Pratyabhijñā, tenth/eleventh c. CE) elaborated the notion that knowledge and consciousness have a close relationship with language. The paper first lays out Bhartrhari's ideas, showing that his theses are rationally defensible and philosophically refined. More specifically, it claims that the grammarian is defending a view which is in many respects similar to 'higher-order theories' of consciousness advanced by some contemporary philosophers of mind. In the second part, the paper shows how Utpaladeva and Abhinavagupta adopted Bhartṛhari's scheme without significant alteration.
\end{abstract}

Keywords Bhartṛhari · Pratyabhijñā · Consciousness · Philosophy of mind · Epistemology

\section{Introduction}

This paper is the second of a series meant to assess the impact the philosopher and grammarian Bhartrhari (460-510 CE) had on the thinkers of the Pratyabhijñā school, most notably Utpaladeva (925-975) and Abhinavagupta (975-1025). A first paper examined how Bhartrihari influenced the Pratyabhijñā's understanding of the notion of svasamvedana, that is, the idea that a cognition must necessarily be selfreflexive and cannot be objectified by another (Ferrante 2017a). The present article

I am grateful to Elisa Freschi and one anonymous reviewer for their precious suggestions. Needless to say, all inaccuracies in this article remain mine.

Marco Ferrante

marco.ferrante@wolfson.ox.ac.uk;

marcoferrante80@gmail.com

1 Wolfson College, University of Oxford, Linton Road, Oxford OX2 6UD, UK 
focusses instead on the claim that all knowledge is dependent on language, which is possibly the thesis where the influence of Bhartrihari on the Saiva school is more evident. ${ }^{1}$

In the first part of this essay I shall reconsider Bhartrhari's ideas on the question. My purpose is to engage with these notions philosophically, in order to show that, although questionable, they are rationally defensible. Accordingly, I shall focus on the structure of the argumentation with reference to contemporary discussions on knowledge and mind. In the second part of the article I will illustrate how the conceptual scheme Bhartrhhari advanced in his Vākyapadīya (VP) is adopted rather faithfully by Utpaladeva and Abhinavagupta.

\section{Preliminaries: Knowledge and Language}

The centerpiece of my analysis are some statements contained in the first chapter of the VP. Specifically, in a group of stanzas gravitating around VP 1.131, the verse in which Bhartrhari maintains that there is a strong connection between language and knowledge. The historical importance of this affirmation is hard to overstate. By reducing all knowledge to the determinate, conceptual type, Bhartrihari distances himself from the milder positions of Mīmāmssā and Nyāya, which accept the existence of both determinate and indeterminate cognitions, as well as from the equally radical view of the Buddhist Pramāṇavādins (which Dignāga is refining approximately in the same period), according to which veridical knowledge is only indeterminate and perceptual. The stanza in question says:

In the world there is no cognition without the pervasion of language. All knowledge shines as if pierced by language. ${ }^{2}$

If we take this statement at its literal value, the author is using two peculiar verbs, anugam- and anuvyadh-, to point out, more or less metaphorically, that language and knowledge are strictly intertwined. Perhaps, he would even go so far as to state that there is an invariable concomitance between the two. ${ }^{3}$

Philosophically speaking, the situation is more intricate and to understand what Bhartrhari thinks we should reflect on the key terms he is using. In the first place, what does he have in mind when he speaks of knowledge? In VP 1.131 the word used to convey the notion is jnāna (together with the synonym pratyaya). As already pointed out by Karl Potter, jñāna indicates a very generic act of awareness that stands for a variety of mental events (beliefs, desires, intentions, knowledge etc.)

\footnotetext{
1 The link between Bhartrhari and the Pratyabhijñā's milieu (or more generally the milieu of the socalled Kashmir Śaivism) is a known fact, which has been discussed by several scholars. Recent contributions, focusing on different aspects of this relationship, are Torella (2008), Rastogi (2009), Timalsina (2013), and Ratié (2018).

2 na so 'sti pratyayo loke yạ̣ śabdānugamād ṛte/ anuviddham iva jñānam sarvam śabdena bhāsate// (VP 1.131). For Bhartrhari’s quotations see Iyer 1966 and Rau 1977.

3 The verb anugam- literally means 'to follow, to go after' but it also expresses the notion of 'penetration'. See the entry anugama in Böthlingk-Roth 1855: 201; anuviddha is glossed as vyāpta by Bhāskara in his commentary on Abhinavagupta's İPV, see vol. 2, p. 297.
} 
having intentional content (i.e. mental events that refer to or are about things); jñāna has thus a broader connotation than that of the related term pramā, which indicates a veridical cognition whose appropriateness is guaranteed by the application of dependable epistemic means. However, both jñāna and pramā presuppose a conception of knowledge that is different from the one developed in Euro-American epistemology. Euro-American thinkers commonly see knowledge as a disposition, in the form of a justified true belief, ${ }^{4}$ while Indian ones tend to regard it as an episodic moment of awareness (Potter 1984, pp. 310-311). The concept of jñāna is thus strikingly similar to the contemporary notion of 'mental representation'. Just like a mental representation, jñāna can be regarded as a mental object possessing intentionality and semantic properties. On this construal, Bhartrhari is therefore saying that all mental representations depend on language.

The other preliminary question concerns precisely what sort of language we are talking about. Bhartrhari is known for having first formulated the idea that language develops progressively and that audible, public speech (vaikharī vāc) is an external manifestation of two inner levels: an intermediate one (madhyamā vāc) and an innermost linguistic principle (paśyantī vāc) from which the two lower stages derive. ${ }^{5}$ If at the vaikhari level speech takes the form of a natural language, Sanskrit in the specific case, the status of madhyamā is more controversial and one can legitimately argue whether it represents instead something altogether different, that is, a 'language of thought' (LoT). The idea behind the notion of LoT (Fodor 1975) is that thinking takes place through a system of symbols that is different from the one we use in speech. This hypothetical idiom, often called 'mentalese', is regarded as an innate code of the mind and as capable of being translated into natural languages. According to the definition Bhartṛhari himself gives in the Vākyapadīya-Vṛtti, madhyamā has three peculiar features: internality (antạ̣saṃniveśa), mind-dependence (buddhimātropādāna) and sequentiality (parigṛhītakrama). Without pushing

\footnotetext{
4 Although also in Euro-American epistemology different positions have recently emerged; the most notable is that of Timothy Williamson (2000), who suggests that knowledge is a mental state; not to mention the problem posed to the traditional stance by the so-called Gettier cases, where one has justified true beliefs without having true knowledge.

5 Vrtti on VP 1.159 paraiḥ saṃvedyaṃ yasyāḥ śrotraviṣayatvena pratiniyataṃ śrutirūpam sā vaikharī. śliṣțā vyaktavarṇasamuccāraṇā prasiddhasādhubhāvā bhrașțasamskārā ca. tathā yākṣe yā dundubhau yā veṇau yā vin̄āyām ity aparimāṇabhedā. madhyamā tv antaḥsamniveśin̄̄ parigṛhītakrameva buddhimātropādānā. sā tu sūkṣmaprāṇavṛttyanugatā kramasaṃhārabhāve 'pi vyaktaprāṇaparigrahaiva keșāñcit. pratisaṃhṛtakramā saty apy abhede samāviṣțakramaśaktị̣ paśyantī. sā calācalā pratilabdhasamādhānā cāvṛtā ca viśuddhā ca, sanniviștajñ̄eyākārā pratilīnākārā nirākārā ca, paricchinnārthapratyavabhāsā saṃsțștārthapratyavabhāsā praśāntasarvārthapratyavabhāsā cety aparimāṇabhedā. "The 'elaborated' word (vaikharī) is that which is intelligible to others, which is grasped by the sense of hearing, it is fixed in each and every case and has an audible character. It is a conjoined [word], a collection of discrete sounds whose correctness is wellestablished or in which the correct grammatical formation is lost. Being present in the axle of a cart, in a drum, a flute or a lute, it possesses unlimited manifestations. The 'middle' word (madhyamā), on the other hand, is internal, it has a sort of temporal sequence and is grasped by the mind only. Yet, according to some, the middle word is pervaded by the activity of subtle breath and, even if in it sequence is contracted, it possesses a detectable [kind of] breath. The 'seeing' word (paśyantī), is that in which sequence is subsumed and, albeit unitary, it is pervaded by the capacity to produce sequence. It is movable and immovable and it is that which is obtained by concentration; it is concealed and pure; it has the form of the contents entering into it, the form in which all contents disappear into it and no form at all; it manifests itself in the form of meanings which are diversified, associated and all rest on it. Hence it possesses unlimited manifestations".
} 
the comparison too far, these three characteristics are rather similar to those contemporary theorists identify in LoT. First, LoT is clearly different from any public language, a feature that corresponds to madhyamā's 'internality'. Second, LoT is exclusively based on the mind - that is madhyamā's 'mind-dependence' for it is conceived as an organized network of mental representations. Third, LoT's basic signs, i.e., mental representations, have a syntactical structure, a feature that approximately corresponds to the notion conveyed by the expression krama, intended as 'regular arrangement'. I am not sure if all this is sufficient to prove that Bhartrhari conceived madhyamā as a form of LoT, but at the same time I do not see crucial evidences showing that it is not. Indeed, the remark made after the definition of madhyamā according to which some thinkers believe that this stage too is based on the activity of breath - an argument for considering madhyamā within the range of natural language - seems to corroborate the idea that Bhartrhari's first option is actually to regard this level as mental. The main advantage of the hypothesis that madhyamā is a LoT is that we come by an elegant picture of the three stages of vāc: vaikharī indicating a natural language, madhyamā a language of thought, and paśyantī representing consciousness. Let me now explore further the consequences of Bhartrhhari's theory which, I will argue, are relevant for a philosophical theory of knowledge even independently on the correct identification of madhyamā as purely LoT, or as linked to a natural language.

\section{What Makes Knowledge Knowledge: The arthakriyā Position}

With the above considerations in mind, let us focus on the criterion to distinguish appropriate knowledge (pramā) from non-reliable cognitions. As is well-known, Indian thinkers have advanced three main theories about the question. The first assumes that a cognition is dependable if it faithfully represents a state of affairs in the external world (yathārtha). Defended by the realist schools of Nyāya, the position is roughly the Indian version of the 'correspondence' theory of EuroAmerican philosophy. The second view is that a cognition is sound when it is in harmony (samvāda) with a network of related cognitions. Traditionally associated with Sāmkhya, this position is historically less influential and can be assimilated to Euro-American 'coherentism'. Finally, a cognition is reliable only if one can perform a successful action (arthakriyā) on its basis. Comparable to Euro-American pragmatic theories of truth, the stance is notably adopted by Buddhist epistemologists. ${ }^{6}$

What about Bhartrhari? Bhartrhari is not particularly keen to discuss epistemological questions and he did not share the idea that knowledge can be classified according to the means we use to cognize (Ferrante 2017b). Furthermore, he does not seem interested in the notion of pramā, which does not appear in this context. Still, if we take jñannas as indicating mental representations, they should have intentionality (they are mental states about something) and, consequently, semantic properties. In other words, jñānas must have features like consistency,

\footnotetext{
$\overline{6}$ See in particular Dharmakīrti's PV 2.1-6.
} 
appropriateness, truth, and accuracy (Pitt 2000). If so, there must be a criterion to establish the appropriateness of jñānas, or as Potter put it, their 'workability' (Potter 1984, p. 318). In this regard, though the question is not addressed straightforwardly, it is clear that Bhartṛhari is preferring the pragmatic, arthakriyā approach over the others. Consider some passages contiguous to 1.131: in 1.129 the author affirms that the awareness of actions carried out in ordinary life is grounded on language. ${ }^{7}$ Then, at the beginning of the Vrtti on 1.131, he states that indeterminate knowledge produces no effect whatsoever unless it is determined by language. ${ }^{8}$ Finally, in 1.135 he claims that it is precisely language that urges all creatures towards successful actions. If it were not for language, he goes on, everything would be as insentient as a piece of wood or a wall. ${ }^{9}$ In all these passages Bhartrhari is using language to indicate a 'linguistically informed knowledge'. Therefore, one can conclude that for him a reliable cognition is a linguistically informed one which is further capable to initiate a successful activity.

\section{Higher-Order Theories of Consciousness and Liminal Cognitions}

Having established that a cognition is reliable if one can perform a successful action on its basis, the next step of the argumentation is to identify what is required to act successfully. Consider the following passage from the Vrtti:

If knowledge were not by nature linguistic, that very vague cognition that has been produced, being unable to contribute to another cognition, would not function as a means to accomplish the action of cognizing. In fact, once there is the cognition of a bare object, whose different parts are not functional to each other and are mutually independent, immediately after comes a unification, a synthesis, the production of a unitary content, that is, the grasping of conjoined capacities as undifferentiated; all this is connected to the linguistic nature of knowledge. ${ }^{10}$

The main development here is that in order to act successfully one must be able to coherently synthesize the experiential data the senses feed into the mind. If that is

\footnotetext{
7 VP 1.129: iti kartavyatā loke sarvā śabdavyapāśrayā/ yāṃ pūrvāhitasaṃskāro bālo 'pi pratipadyate//"In the world all that is required to be done is dependent on language. A child too understands it on the basis of the traces of previous births".

8 Vrtti on 1.131: yathāsya saṃhṛtarūpā śabdabhāvanā tathā jñeyeșv artheșūtpannenāpy avikalpena jñānena kāryam na kriyate. "Just like one has a verbal potentiality in a contracted form, similarly no effect is produced by indeterminate knowledge, even if it arises in relation with objects that are [already] known".

9 VP 1.135: arthakriyāsu vāk sarvān samīhayati dehinaḥ/ tadutkrāntau visaṃjño 'yaṃ dṛ́yate kāṣthakuḍavat// "Language urges all creatures towards successful activities. If it were to disappear, all this world would be unconscious like a piece of wood or a wall".

10 Vṛtti on VP 1.132: vāgrūpatāyām cāsatyām utpanno 'pi prakāśạ pararūpam anañgīkurvan prakāśanakriyāsādhanarūpatāyāṃ na vyavatișthate. bhinnarūpānām cānupakārināām ātmāntarānātmanām itaretarasya vastumātrājñāne pratyavabhāsamāne yad uttarakālam anusaṃdhānam pratyavamarśa ekārthakāritvam avibhāgena śaktisaṃsargayogopagrahas tad vāgrūpatāyām bạdham.
} 
not the case, cognitions will remain detached one from another, thus being unable to contribute to "the action of cognizing". 11 This emphasis on coordination of cognitions suggests that in order to be epistemically reliable, cognitions must be made conscious by a higher-order representation. Bhartrhari is thus maintaining a position that today would be categorized as a 'higher-order theory of consciousness'. Very broadly speaking, some contemporary philosophers of mind seek to explain consciousness in terms of neural, physical states, while others claim that consciousness comes down to some sort of mental representation of the sensory data. The latter view is further split: some theorists believe that all we need to explain consciousness are first-order mental representations, namely world-directed ones. Others argue that what makes a mental representation conscious is the fact that it is itself the content of a higher-order representation, that is, of a metacognition. Higher-order theories must further satisfy another requirement: for reasons that will be clear below, they must recognize the existence of unconscious mental representations alongside with conscious ones. This means that if I am to claim that Bhartrhari is conceiving consciousness and cognitions in higher-order terms there must be passages in his work suggesting that some cognitions can be entertained unconsciously. A positive answer to this question is to be found in Vincenzo Vergiani's discussion of 'liminal cognitions' (Vergiani 2012). Liminal cognitions are mental representations that one has unconsciously, typically because they happen very quickly or one's attention is focused elsewhere. They are liminal because they are in-between: they are unconscious but not altogether different from conscious ones, mainly because they can be brought back to awareness later on through memory. An example is given right in the Vrtti on 1.131, where the author talks of somebody walking fast without being consciously aware of the grass and clods of earth she is proceeding through. ${ }^{12}$ Again, the text explains the unconscious nature of these mental representations with the fact that one cannot initiate any action on their basis. In sum, Bhartrhari is claiming that to act successfully one requires an awareness of one's own mental representations. This awareness is produced by second-order representations that operate on first-order ones, which are in turn determined by experience. But Bhartrhari also holds, and this is of course critical, that higher-order representations are language-driven.

\section{Language and Higher-Order Models of Consciousness}

Contemporary supporters of higher-order theories of consciousness diverge on the nature of higher-order representations. Some argue that they are conceptual, others claim they are purely perceptual. Without delving into the reasons in favor of one model or another, it is evident that Bhartrhari endorses the latter view and that for

\footnotetext{
11 Bhartrhari is also consciously identifying the process of knowledge-acquisition with that of meaningacquisition. Isolated cognitions are thus compared to the kārakas which, without an overarching synthesis, are inherently unable to contribute to the realization of the verbal action (karman). This is the interpretation Vṛṣabhadeva's Spḥutākṣarā favors in discussing this passage.

12 Vṛtti on VP 1.131: tadyathā tvaritam gacchatas ț̣naloṣṭādisamsparśāt saty api jñāne... "For instance, even if somebody walking fast has knowledge from the contact with grass and lumps of earth..."
} 
him a higher-order representation is a conceptual affair. The point is whether conceptual activity necessarily entails language. Bhartrhari clearly believes it but he does not produce direct proofs in support. One can nevertheless hypothesize some explanations. A first one is to conceive a concept as innately based on language. All in all, such a position is shared by most Indian thinkers and is quite common also in contemporary Euro-American thought, where concepts have become more and more often identified with meanings. Furthermore, the very notion of higher-order thoughts seems to imply a connection with verbal reportability, hence with speech (Rosenthal 2009, pp. 243-244). A second explanation is related to the aforementioned discussion of LoT. If we accept the idea that Bhartrhari conceives language as having a mental dimension, the assumption that conceptual activity calls for language can be argued for in a weaker form, by saying that what is required to cognize is a correct syntactical arrangement of the contents of mind but not necessarily a natural language. Finally, consider also that the lack of a substantial defense of this claim in the VP does not imply that the thesis is not defendable. There are several contemporary theorists (Davidson 1975; Bermudez 2003) who would argue that language is required to entertain concepts. In any case, it is hardly questionable that Bhartrhari does not offer a clear-cut explanation of the fact.

\section{The Problem of svasatmvedana and Self-representational Cognitions}

The picture I have conjured up so far I think it correctly represents Bhartrhari's view. There is nonetheless a potentially fatal objection to this account. To admit the existence of higher-order representations implies that these representations act on first-order ones. This goes against an epistemic principle Bhartrihari embraces, which is the idea that a cognition cannot be the content of another, for cognitions are by nature self-conscious. ${ }^{13}$ If this is true, to hypothesize that higher-order cognitions make the first-order ones conscious would lead to infinite regress, for one would require third-order cognitions to make the second-order conscious, and so on.

There are essentially two options to meet the objection. The first is to argue, in line with contemporary theorists, that higher-order mental representations are unconscious. Since there is no need to grant consciousness to them, infinite regress is avoided. In our specific case this would mean that the action of coordination of cognitions that Bhartrhari regards as crucial to having reliable knowledge is not experienced consciously, which on the whole looks like a tenable position. But there is also a second way to overcome the objection. By reading carefully the stanzas and the commentary under analysis, one cannot fail to notice how often the author emphasizes that language, hence higher-order representations, is operative at all cognitive levels. He claims that even the most immediate perceptions have a conceptual content without which no activity can be undertaken. These remarks allow us to refine his view as follows. When he is defining the nature of a conscious state, Bhartrhari is not thinking of a different cognition having the first as its

\footnotetext{
13 For a detailed discussion of Bhartrihari's position on self-awareness of cognitions (svasamvedana) and his impact on the Pratyabhijñā see Ferrante (2017a).
} 
content. On the contrary, a first-order representation already possesses within itself its higher-order counterpart, thus leading to the conclusion that cognitions are selfrepresentational. Differently put, mental representations seem to possess two aspects, a world-directed and metacognitive one, which occur simultaneously. This view is not unfamiliar to specialists in Indian thought, since it is very close to Dharmakīrti's notion that knowledge has both perceptional and judgmental (niścaya) sides. And it is also very similar to the notion of 'intrinsic higher-order content' proposed by some contemporary philosophers of mind to address some difficulties posed by standard higher-order theories. ${ }^{14}$

\section{Summary}

What we have said so far can be summarized as follows:

(1) I have started with the assumption that the notion of 'cognition' (jñāna, pratyaya) is equivalent to that of 'mental representation'. This is because Indian thinkers normally conceive knowledge as an intentional episodic awareness, rather than a disposition of the mind. Though different from pramā, also jñāna has truth-conditions. In force of that, there must be a criterion to distinguish between appropriate and non-appropriate cognitions.

(2) According to Bhartrhhari this criterion consists in cognitions' causal efficiency (arthakriyā), i.e., the possibility to act successfully on the basis of a given mental representation.

(3) One can initiate a successful action only through a synthesis of first-order, world-directed mental representations. Such a synthesis is guaranteed by higherorder representations that are conceptual.

(4) Bhartrhari assumes that these higher-order, conceptual representations are rooted in language, be it natural or mental. The VP does not provide substantial evidence for this thesis, which it is nevertheless defensible.

(5) Bhartrihari further holds that a cognition is self-conscious and never the object of another. But he also believes that higher-order representations (that is, concepts and language) are present in all cognitive states. This entails that each mental representation is at the same time experience-directed (it is about something) and self-directed (it is about itself), thus being capable to generate a higher-order thought of itself.

(6) the conclusion is that in order to have cognitions, and to be conscious in general, language is required.

\footnotetext{
${ }^{14}$ For a critical overview of higher-order theories see Carruthers (2016). 'Intrinsic-content' theories are defended by Carruthers (2000) and Gennaro (2005).
} 


\section{Pratyabhijñā's Appropriation of Bhartṛhari's Conceptual Scheme}

The impact on Utpaladeva and Abhinavagupta of the picture just put together is huge. Consider first Abhinavagupta's IPV on 1.5.13 (Torella 2002), where Utpaladeva affirms that between language and consciousness a close relationship obtains:

The word citi 'consciousness', derives from the verbal root citi in the expression cetayati, 'to make conscious'; its essential nature is a reflexive awareness characterized by self-savoring. To explain: a pot does not have a self-savoring, it does not have a reflective awareness and for this reason it does not shine independently, nor it is manifested as having an uninterrupted nature. This is why it is said that [a pot] is unconscious. In contrast, [a person named] Caitra has self-savoring, for he has the power to manifest a tension towards an elevated state, that is, the 'I'; he possesses reflexive awareness and shines by itself. A limited manifestation-appearing as 'this'-appears in such a form that it is different from the 'I', for it is affected by innumerable [limited] manifestations like blue, yellow, pleasure, pain, their absence etc. Therefore, it is said that Caitra is conscious. Thus, that both reflexive awareness and non-reflexive awareness are confined to themselves is not at all established, for reflexive awareness is capable of everything: it makes what is different from itself identical and itself a different thing; it brings together both difference and identity, and demotes both of them, which were [previously] unified. This is its essential nature. Reflexive awareness's essential nature is a subtle verbalizing, consisting in inner speech. This 'subtle verbalizing' is an uninterrupted spontaneous savoring and is independent from linguistic convention. It is like an internal nodding of the head; it is the life of the conventional sounds that exist at the Māyā level, such as 'a' etc., because it is the internal background of self-reflexive cognitions such as 'this is blue', 'I am Caitra' and so on. Since speech denotes all things through reflexive awareness, [consciousness] is said to be the 'word' (vāc). [The word] is supreme because of its completeness. Hence, having a conscious nature and resting on itself, it arises freely, it never declines, it exists permanently as the 'I'. This primary freedom of the supreme self is defined as its sovereignty, supremacy and independence from others. ${ }^{15}$

\footnotetext{
15 cetayati ity atra yā citịh citikriyā tasyāḥ pratyavamarśạ svātmacamatkāralakṣaṇa ātmā svabhāvaḥ. tathā hi ghațena svātmani na camatkriyate, svātmā na parāmṛśyate, nā svātmani tena prakāśyate, na aparicchinnatayā bhāsyate, tato na cetyata iti ucyate. caitrena tu svātmani aham iti samrambhodyogollāsavibhūtiyogāt camatkriyate, svātmā parāmṛ́syate, svātmany eva prakāśyate, idam iti yah pariccheda etāvadrūpatayā tadvilakṣaṇībhāvena nīlapītasukhāduḥkhatacchūnyatādyasaṃkhyāvabhāsayogena avabhāsyate, tatạ caitreṇa cetyata iti ucyate. evam ca vimarśạ svātmani avimarśo 'pi svātmani ity asiddham etat. vimarśo hi sarvaṃsahah param api ātmīkaroti, ātmanam ca parīkaroti, ubhayam ekīkaroti, ekīkrtaṃ dvayam api nyagbhāvayati ity evaṃsvabhāvaḥ. pratyavamarśaś ca āntarābhilāpātmakaśabdanasvabhāvaḥ, tac ca śabdanaṃ saṃketanirapekșam eva avicchinnacamatkārātmakam antarmukhaśironirdeśaprakhyam akārādimāyīyasāṃketikaśabdajīvitabhūtam. nīlam idam caitro 'haṃ ityādipratyavamarśāntarabhittibhūtatvāt, pūrṇatvāt parā, vakti viśvam abhilapati pratyavamarśena iti ca vāk, ata eva sā svarasena cidrūpatayā svātmaviśrāntivapușā uditā sadānastamitā nityā aham ity eva. etad eva paramātmano mukhyạ̣ svātantryam aiśvaryam îsitț̣tvam ananyāpekṣitam ucyate. İPV 1.5.13, vol. 1, pp. $250-254$.
} 
Take then into account a further passage, this time from the IPV on 1.5.19, where Utpaladeva claims that conceptual thinking is at work also in seemingly immediate cognitions:

Even admitting that an immediate cognition is by nature momentary, in that too there is reflexive awareness. This is necessary. How could it be otherwise? In fact, if it were not so [i.e. if there was no reflexive awareness in the case of immediate cognitions], then a person proceeding rapidly with a specific purpose, or reciting letters quickly, or reading fast a book of mantras, would not reach, pronounce or recite what she has in mind. To explain: how can a person reach the place she has in mind without a reflexive awareness, whose essential aspect are unification and separation, and consists of the knowledge of the place, the will to proceed, the actual proceeding, the awareness of the movement, the unification of another purpose, the desire to leave, the knowledge of a different place, the desire to proceed towards it and so forth? The same applies to reading quickly, speaking etc. where, specifically, there is a union between places and organs of articulation etc. Since here one does not experience a gross conceptual cognition as following the immediate one, there is quickness. Therefore, there must be a subtle reflexive-awareness consisting of verbal potentiality in a contracted form, because one gets a gross conceptual cognition when a verbal potentiality becomes manifest by expansion. ${ }^{16}$

If we select the relevant information contained in these passages, Bhartrhari's conceptual scheme emerges clearly:

(1) mental representations/cognitions (which the Pratyabhijñā authors call prakāśa) are conscious in so far as they are the content of higher-order representations (an activity the Śaiva thinkers call vimarśa/pratyavamarśa/parāmarśa). Like in Bhartrhari's view, these mental representations are presumably produced at the same time of cognitions. This is why Abhinavagupta says that consciousness consists in an act of "reflexive awareness characterized by self-savoring" and that it is the capability of the mind "to produce an effort towards a raised state, that is the I".

(2) higher-order representations have a linguistic nature. In Abhinavagupta's words: 'This 'subtle verbalizing' is an uninterrupted spontaneous savoring and is independent from linguistic convention. It is like an internal nodding of the head; it is the life of the conventional sounds that exist at the Māyā level, such as ' $a$ ' etc., because it is the internal background of self-reflexive cognitions such as 'this is blue', 'I am Caitra' and so on. Since speech denotes all things through reflexive awareness, [consciousness] is said to be the "word"'.

\footnotetext{
16 bhavatu vā kṣaṇamātrasvabhāvaḥ sākșātkāraḥ, tatrāpi asti vimarśaḥ. avaśyam caitat. katham anyathā iti. yadi sa na syāt tat ekābhisaṃdhānena javāt gacchan, tvaritaṃ ca varṇān paṭhan, drutạ̣ ca mantrapustakaṃ vācayan, na abhimatam eva gacchet uccārayet vā vācayet vā. tathā hi tasmin deśe jñānam-ācikramișāākramaṇam-ākrāntatājñ̄anam-prayojanāntarānusaṃdhānam-tityakșā-deśāntarānusaṃdhih, tatrāpi ācikramiṣā ity ādinā yojanāviyojanarūpena pratyavamarśena vinābhimatadeśāvāptih katham bhavet. evam tvaritodgrahanavācanādau mantavyam. tatra viśeșatạ sthānakaraṇākramaṇādiyogah. atra ca yatah paścād bhāvisthūlavikalpakalpanā na saṃvedyate, tata eva tvaritatvam iti sūkṣmeṇa pratyavamarśena samvartitaśabdabhāvanāmayena bhāvyam eva. saṃvartitā hi śabdabhāvanā prasāraṇena vivartyamānā sthūlo vikalpah. İPV 1.5.19, vol. 1, pp. 290-293.
} 
(3) action entails a conceptualization, a coordination of cognitions, a mental function the Śaivas calls anusaṃdhāna (or pratisaṃdhāna), ${ }^{17}$ which is by the way the very same word Bhartrihari uses in the Vrttti on 1.132. Thus Abhinavagupta affirms that "if it were not so [i.e. if there was no reflexive awareness in the case of immediate cognitions], then a person proceeding rapidly with a specific purpose, or reciting letters quickly, or reading fast a book of mantras, would not reach, pronounce or recite what she has in mind. To explain: how can a person reach the place she has in mind without a reflexive awareness, whose essential aspect are unification and separation, and consists of the knowledge of the place, the will to proceed, the actual proceeding, the awareness of the movement, the unification of another purpose, the desire to leave, the knowledge of a different place, the desire to proceed towards it and so forth?"

I think these passages are sufficient to show how deep was the impact on Pratyabhijñā's philosophy of the doctrines elaborated by Bhartrhari and summarized above. One can even go as far as to ask what the Śaiva thinkers added to Bhartrhari's picture. Leaving aside their theistic attitude, I think they supplemented this basic scheme with three main contributions: the first and by far most important is the emphasis on the apparently mysterious notion that vimarśa, i.e. higher-order representations, has savoring. As I argue more in detail elsewhere, ${ }^{18}$ the Śaivas are probably referring to the fact that conscious experience has a subjective, phenomenal, 'what it is like to be' dimension - a 'savoring' if you want-that is in many respects difficult to render in terms of mental representations and which can be pointed out only metaphorically. This is without doubt the most sophisticated aspect of the Śaivas' conception of consciousness, an aspect that in Bhartrhari's work does not seem to emerge. The second point is the systematic rejection of the skeptical stance the Buddhists have on the epistemic status of concepts and language, whereby any form of conceptualization is eventually pseudo-knowledge. The third and final element is Pratyabhijñā's tendency to espouse a much more radical version of non-dualism, developing the idea that external objects have the same nature as mind/consciousness and that cognitions always entail an awareness of the knowing subject.

\section{Conclusions}

In this paper I have tried to show that Bhartrhari's oft-quoted and sometimes misunderstood notion that knowledge is ingrained in language is rationally defensible. In particular, Bhartrhari is not rejecting the existence of indeterminate cognitions. Indeterminate cognitions are real mental representations but are by themselves unable to initiate a successful activity. To acquire the status of useful knowledge, they require a process of cognitive synthesis, which is based on higher-

\footnotetext{
$\overline{17}$ See İPK on 1.3.6 and İPKVṛ 1.5.19.

18 See Ferrante forthcoming.
} 
order representations that are always language-dependent. Whether this language is to be intended as a natural one or a language of thought is not totally clear to me, even if I believe that the overall picture I have proposed is not altered by accepting either view.

The conceptual scheme that Bhartrhari offers in the VP proves to be extremely influential to the philosophy of the Pratyabhijñā. Utpaladeva and Abhinavagupta embrace it without substantial modification, emphasizing some theoretical aspects (a stronger non-dualistic outlook, both ontologically and epistemologically) and defending the scheme from the criticism of the Buddhist Pramānavādins.

A final remark on the historical contextualization of these ideas is called for. It is quite clear that both the notion of arthakriyā and the one whereby cognitions have content-oriented and metacognitive sides, show a remarkable resemblance to the doctrine of the Buddhist Pramāṇavāda. This should make us reflect on two related aspects: the necessity to have a better historical evaluation of the relationship between the work of Bhartrhari and that of Buddhist epistemologists; but also the centrality this thinker had in the history of Indian philosophical discourse. All in all, Bhartrhari was arguably the most influential Brahmanical thinker of the first millennium CE, on a par with Kumārila.

Open Access This article is distributed under the terms of the Creative Commons Attribution 4.0 International License (http://creativecommons.org/licenses/by/4.0/), which permits unrestricted use dis tribution, and reproduction in any medium, provided you give appropriate credit to the original author (s) and the source, provide a link to the Creative Commons license, and indicate if changes were made.

\section{References}

\section{Sanskrit Texts}

[ĪPV] Abhinavagupta. Íśvarapratyabhijñāvimarśinī. Ed by. K.A Subramania Iyer and K.C. Pandey. Motilal Banarsidass, 1986.

[ĪPK] Utpaladeva. İ́sarapratyabhijñākārikā and Vṛtti. See Torella 2002.

[PV] Dharmakīrti. Dharmakīti's Pramāṇavārttika with a commentary by Manorathanandin. Edited by Rāhula Sānkrtyāyana. Appendix to Journal of the Bihar and Orissa Research Society 24-26 (19381940).

[VP] Bhartṛhari’s Vākyapadīya. See Iyer 1966 and Rau 1977.

\section{Secondary Literature}

Bermudez, J. L. (2003). Thinking without words. Oxford: Oxford University Press.

Böthlingk, O., \& Roth, R. (1855). Sanskrit Wörterbuch. Saint Petersburg: Kaiserlichen Akademie der Wissenschaften.

Carruthers, P. (2000). Phenomenal consciousness: A naturalistic theory. Cambridge: Cambridge University Press. 
Carruthers, P. (2016). Higher-order theories of consciousness. In E. N. Zalta (Ed.), The Stanford encyclopedia of philosophy (Fall 2016 Edition). Retrieved from https://plato.stanford.edu/archives/ fall2016/entries/consciousness-higher/.

Davidson, D. (1975). Thought and talk. In S. Guttenplan (Ed.), Mind and language (pp. 7-23). Oxford: Clarendon Press.

Ferrante, M. (2017a). Studies on Bhartṛhari and the Pratyabhijñā: the case of svasamvedana. Proceedings of the conference of the society for the tantric studies. Religions, 8, 145. https://doi.org/10.3390/ rel8080145.

Ferrante, M. (2017b). Bhartrhari and verbal testimony. A hyper-antireductionist approach? In D. Cuneo, E. Freschi, \& C. Formigatti (Eds.), Not far afield: Asian perspectives on sexuality, testimony and print culture. A coffee break project. Kervan (Vol. 21, pp. 227-246).

Ferrante, M. (Forthcoming). The Pratyabhijñā on consciousness and self-consciousness: A comparative perspective.

Fodor, J. (1975). The language of thought. New York: Crowell.

Gennaro, R. J. (2005). The hot theory of consciousness: Between a rock and a hard place? Journal of Consciousness Studies, 12, 3-21.

Iyer, S. (1966). Vākyapadīya of Bharțhari with the Vịtti and the Paddhati of Vṛ̦abhadeva. Pune: Deccan College.

Pitt, D. (2000). Mental representation. In E. N. Zalta (Ed.), The Stanford encyclopedia of philosophy. https://plato.stanford.edu/archives/win2018/entries/mental-representation/.

Potter, K. H. (1984). Does indian epistemology concern justified true belief? Journal of Indian Philosophy, $12,307-327$.

Rastogi, N. (2009). Vāk as Pratyavamarśa: Bharțhari from Abhinavan perspective. In M. Chaturvedi (Ed.), Bhartrhari: Language, thought and reality. Proceedings of the international seminar (pp. 301334). Delhi: Motilal Banarsidass.

Ratié, I. (2018). On the Șaḍdhātusamīkșā, a lost work attributed to Bhartṛhari: An examination of testimonies and a list of fragments. Journal of the American Oriental Society, 138(4), 709-741.

Rau, W. (1977). Bharț̣hari's Vākyapadīya. Die Mūlakārikās nach den Handschriften herausgegeben und mit einem pāda-index versehen. Wiesbaden: Franz Steiner GMBH.

Rosenthal, D. M. (2009). Higher-order theories of mind. In B. McLaughlin, A. Beckermann, \& S. Walter (Eds.), The Oxford handbook of philosophy of mind (pp. 239-252). Oxford: Oxford University Press.

Timalsina, S. (2013). Linguistic and cosmic powers: The concept of Śakti in the philosophies of Bhartṛhari and Abhinavagupta. In P. Pratap Kumar, \& J. Duquette (Eds.), Classical and contemporary issues in Indian studies: Essays in honour of Trichur S. Rukmani (pp. 211-232). Delhi: DK Printworld.

Torella, R. (2002). The İ́varapratyabhijñākārikā of Utpaladeva with the Author's Vṛtti. Delhi: Motilal Banarsidass.

Torella, R. (2008). From an Adversary to the main Ally: The place of Bhartrhari in the Kashmirian Shaiva Advaita. In A. Aklujkar \& M. Kaul (Eds.), Linguistic traditions of Kashmir: Essays in memory of Pandit Dinanath Yaksh (pp. 508-524). Delhi: DK Printword.

Vergiani, V. (2012). Bhartṛhari's views on liminal perception and self-awareness. In C. Watanabe, M. Desmarais, \& Y. Honda (Eds.). Samskṛta-sādhutā. Goodness of sanskrit, studies in honour of professor Ashok Aklujkar (pp. 470-487). Delhi: DK Printworld.

Williamson, T. (2000). Knowledge and its limits. Oxford: Oxford University Press.

Publisher's Note Springer Nature remains neutral with regard to jurisdictional claims in published maps and institutional affiliations. 